\title{
Reconstructions of Serbian National Identity in the Post-Yugoslav Era: A Thematic Survey
}

\begin{abstract}
This paper surveys some of the challenges facing Serbia in reconstructing elements of its national identity following the break-up of Yugoslavia in the 1990s. Unlike most of the other republics that comprised the federation, Serbia fought to maintain the Yugoslav federation, and so to that extent was the least nationalist of the republics at the beginning of the 1990s. However, as Yugoslavia disintegrated in that decade, Serbia was forced to reconstruct its identity in ways that reflected the unprecedented circumstances it was confronting. This paper explores elements of the ongoing process of Serbia's identity-reconstruction since the 1990s, focussing on notions of hybridised national identity, the influence of historical tropes, and the tensions between cultural homogeneity and the subversive effects of globalisation on this identity. What emerges from this study is that contemporary Serbian national identity has consequently become a dynamic and evolving construct, and is continually being redefined as it responds to internal tensions and external pressures.
\end{abstract}

Keywords: Serbia, history, homogeneity, hybridity, identity, culture, orthodox, religion, nationalism

\section{Introduction}

Amid the political, social, cultural, and economic convulsions that accompanied the disintegration of Yugoslavia in the 1990s, accusations of „ultra"-nationalism were at times levelled at all sides, but most frequently at the Serbs (Hislope 1996, 471; Morus 2007, 3-7) who were portrayed by many Western governments and in the Western media generally as nationalist-fuelled aggressors (Friedman 1993; Sciolino 1994; Congressional Quarterly 2013,214; Stedman 1992, 1-16; Sobel 1998, 250-278), acting out an expansionist agenda against its non-Serb compatriots (the so-called „Greater Serbia" project) (Guzina 2003, 91-111; Caspersen 2008, 359-360). Ironically, some Serbs in the late 1980s and early 1990s still favoured a federal 
Yugoslavia over any separatist movements. President Slobodan Milošević had echoed such a sentiment in 1989, asking critics of the federal Yugoslavia, „Why are they disturbed by the homogenization of peoples and human beings in general if it is carried out on the basis of just, humane, and progressive ideas $[\ldots]$ and is of no harm to others? Is this not the meaning, the aim, to which humanity has always aspired?" (Milošević 1989, 334). However, while the maintenance of a multi-national and multi-ethnic federal state was still an ideal for some Serbs, reflecting Tito's long-held aspiration that the country become ,a community of a single Yugoslav nation, in which our five peoples would become a single nation" (J. B. Tito in Banac 1990, 152), the more lasting strategic ideal in Tito's construct of the Yugoslav state was the creation of the multi-ethnic federation without a leading nation. In this socialist model, Serbian identity was defined as one of many equal identities in the same country. Ideologically, the essence of Titoism was thus not unitarism but multi-ethnic federalism.

There were signs, however, of a more assertive Serbian voice emerging in latter stages of the Yugoslav socialist era. The famous 1986 Memorandum of the Serbian Academy of Sciences and Arts, for example, promulgated the expression of a more cohesive form of Serbian cultural identity (Pavković 1998), while the Serbian politician, writer, and academic, Dobrica Ćosić, depicted Serbian commitment to this federalism in 1989 increasingly as an unappreciated burden, especially in the face of rising nationalism in other parts of Yugoslavia. "Let us stop once and for all to liberate, save, and safeguard others", he wrote, „to keep convincing them that they would perish without us. If they do not wish to live with us in a democratic federation, let us respect their wish to be alone and happy"(Ćosić 1989, 6). Around 1990, the Serbian attitude to a national identity was still seemed to be lodged, albeit ambivalently for many, in the notion of a federal Yugoslavia.

When Yugoslavia finally fragmented into six nation-states (each with their supposedly discrete ethnic, linguistic, and cultural identities) (Greenberg 2004; Sekulić, Massey and Hodson 1994; Goulding and Domic 2009; Weinstein, Warshauer Freedman and Hughson 2007), Western presumptions about Serbian ultra-nationalism persisted. This form of nationalism was depicted as not just being axiomatic in the dissolution of Yugoslavia in the decade, but existing as the grim antithesis of an increasingly idealised portrayal of the federal Yugoslavia that had existed until at least the early 1980s (Lendvai 1991, 251-252). The confluence of Yugoslavia's demise with the metanarrative of the fall of communism in Europe in the preceding decade had the effect of casting Serbian nationalism in the 1990 s as a necessary evil (in that it brought about the destruction of a communist state), but an evil nonetheless (Gagnon 1994; Pešić 1996). 
Many of the challenges that the re-formed Serbian state faced - particularly economically and in international relations - have been well documented. ${ }^{1}$ However, considerably less attention has been devoted to how Serbs and Serbia have reconstructed their identity in the wake of Yugoslavia's disintegration. This work establishes a selection of the generic elements that constitute national identity for modern nation-states, and then surveys three (often overlapping) dimensions to identity formation that apply to Serbia's experience since the 1990s: the hybridisation of national identity; the appropriation of historical tropes to aid identity formation and re-formation; and the importance of homogeneity (or 'categorization') (Brubaker and Cooper 2000, 14) as a component of contemporary Serbian identity. These elements are applied in an expansive and generalised way in order to prevent them from becoming too prescriptive. The article concludes with an assessment of those factors that potentially unsettle this identity, and a consideration of the subversive pressures that globalisation is bringing to bear on conventional understandings of Serbia's national identity.

\section{Bases for National Identity}

In order to evaluate selected aspects of the reconstruction of Serbia's national identity since the 1990 s, it is useful to construct a theoretical framework which establishes the parameters of the subsequent analysis. The literature on national identity is vast, and encompasses works from various ideological perspectives, as well as studies which tackle a range of aspects of national identity, from political and economic influences, to the roles of history, geography, language, culture, religion, and art, literature, music, psychology, among others (Erikson 1980, 66-67, 76). What is established here is a fairly porous model that incorporates in a cursory manner some of the major tenets of modern national identity-construction, drawing largely on Social Identity Theory, and which can then be applied to the reconstruction of Serbian identity in the last three decades.

At the heart of most branches of Social Identity Theory is a duality, in which individuals possess their own unique identities, but simultaneously are bound by a common group identity (with the group existing in vastly different forms and scales) (Tajfel and Turner 2004). Membership of the group provides positive forms of individual validation (Brown 2000, 747), that in turn lead to the group differentiating itself from and even discriminating against those outside it as a means of reinforcing its senses of authenticity, rectitude, and purpose.

${ }^{1}$ As indicative examples, see M. Stamatović, and N. Zakić 2010; S. Economides, and J. Ker-Lindsay 2015. 
A distinction emerges at this juncture between notions of self-esteem - which presumably are a component of every national and ethnic identity - and efforts to achieve delineation from the Other. These are counteracting forces in their origin, but potentially lead to an enhanced ethnic or national identity in combination with each other (Lemyre and Smith 1985, 660-670; Oakes and Turner 1980, 295-302). At the level of a national identity, this can have significant implications for relations between peoples with different perceptions of their identities, extending even to xenophobic attitudes in some instances (Brown 2000, 748; Brown, Vivian and Hewstone 1999, 741-764; Gonzalez and Brown 1999). In such an environment, stereotypes of the group (and of those outside the group) are not so much distortions of reality which need to be remedied through more impartial and informed assessments of the group's environment, but instead function as „rather reliable guides to judgement and action” (Brown R. 2000, 750; Tajfel 1981, 144-167).

In the case of the emergence of a reconstructed Serbian identity from the early 1990s onwards, it is easy to detect examples which illustrate aspects of these traits. Whereas in preceding decades, Yugoslav identity had been the principle group which provided validation to (most of) its members (Sekulić, Massey and Hodson 1994; Burg and Berbaum 1989) with the breakup of that entity, and with groups formerly a part of it acquiring more distinct and pronounced ethnic identities of their own, the materialisation of a Serbian national identity (which had existed historically in very marked forms (Bieber 2002, 95-110) and which had similar bases, motives, and environmental prompts for a re-emergence in this new environment), was inevitable.

At this point, the issue of whether Serbian national identity in this embryonic reconstructed form emerged as a response to external stimuli, or whether its appearance promoted other groups to become more strident in their own national identity emerges. The answer is not necessarily a binary one and in practice is so complex that it is virtually impossible of disentanglement. The pervasive influence of propaganda, the partiality of media within each national group, the involvement of external political and religious players, the appropriation of selective histories and the subsequent mythologizing of those histories, the near-utopian prospects held out for the formation of new nation-states based on homogeneous national-ethnic groups, all set against a backdrop of the declining economic fortunes of the Yugoslav state, makes single-cause explanations of the basis of the reconstructed Serbian national identity not just misleading but meaningless.

Another dimension to the nature of reconstructed nationalism comes from Eric Hobsbawm, whose historical, as opposed to psychological account of nationalism serves as a useful counterpoint to Social Identity Theory. Hobsbawm argued that it was more profitable to deal with the concept of nationalism than 
the nation it represented, as the former preceded the latter and offered more insight into the phenomenon (Hobsbawm 1972, 387). Hobsbawm drew in part on Ernest Gellner's construct of nationalism, in which one of the essential components of the concept was the congruence of a political, national (and by implication, ethnic) unit (Gellner 2008, 1) (which is refined by Barth's notion of identity as ,the social organisation of cultural difference”) (Barth 1998, 6). The construction of a group (and at this point, the intersection with Social Identity Theory becomes apparent) emerges as the central prerequisite of the construction of a nation, even if that group's identity was based on beliefs that were „patently not so" (Hobsbawm 2012, 12). In addition, Hobsbawm identified the paradox that tends to be overlooked by nationalists of all persuasions: that contemporary forms of nationalism, and the nations they give rise to are not the result of some primordial history, but are, ironically, the products of modernity (Hobsbawm 2012, 14). So while appeals to history to buttress nationalist claims are an intrinsic part of nationalism, the form of that nationalism, and the ensuing states that often emerge from it, are entirely modern entities with barely any connection to the historical period they invoke. Such traits were (and are) evident to varying degrees in all the states of the former Yugoslavia, ${ }^{2}$ and function to provide a dimension of legitimacy by supporting contemporary nationalist claims with historical „evidence”. Dubravka Stojanović has described both the historiography and the teaching of history in Serbia between 1993 and 2008 as having ,served more as forms of preparatory military training than as scholarly disciplines of critical thinking" (Stojanović 2009, 141), while as early as 1994, Sima Ćirković argued that „Serbian historiography has now been torn out of its international context, with a consequent interruption of dialogue and a return to autarkic national historiography of the beginning of the century, resulting in a weakening of its position in dialogue with the national cultural environment" (Ćirković 1994, 36).

\section{Hybridised Identity}

One of the great ironies of the reconstructions of national identities in the area of the former Yugoslavia is that they have followed remarkably similar patterns - particularly in the nexus of culture, politics, and history, and in the efforts to differentiate the similar, as, for example, in the case of what was previously known as the Yugoslav language (Ljubesic, Mikelic and Boras 2007). While there were pronunciation and dialectical variations in this language (Greenberg

2 The most extreme example being Kosovo* which never existed as a state or as a discrete ethnic group, yet now has an entire myth-cycle associated with its supposed history.

Етноантрополошки проблеми, н. с. год. 13 св. 4 (2018) 
1996), upon the formation of new nation-states from the former Yugoslavia, this language was claimed by multiple groups as part of the reconstruction of their new national identity. Thus, languages such as Serbian, Croatian, Bosnian, and even Montenegrin came into existence for purely identity reasons, even though such initiatives defied the obvious fact that they are all a single language, and that variants within some of these languages (such as ,deda" and „dida" in different regions of Croatia) were greater than the variants between these languages (such as „deda” being used in parts of Croatia and almost all of Serbia) (Miličević 2017).

This example illustrates the process of identity-hybridisation, in which elements from different cultural or national groups are drawn together to constitute a new cultural or ethnic group. Within newly-constituted states, the same processes are often at work, making hybridisation one of the components of the reconstruction of national identity. The importance of this process is that it offers what Homi Bhabha has identified as new sites of political agency (Bhabha 1994, 264-265). This creates a symbiotic relationship, in which those new sites of political agency serve as a scaffold to prop up reconstructed forms of cultural identity, which, in turn, demand stronger political agency to support them. However, as this cycle continues, it also produces political tensions and cultural ambivalence as the identity-reconstruction becomes more revolutionary and politically orientated than evolutionally and social and culturally orientated.

One example of this in the Serbian context is the role of Serbian leaders since the 1990s as mouthpieces for expressions of Serbian national identity to an extent that would be unfamiliar in most other developed countries. Milošević's famous appeal in 1987 to Serbs living in the southern Serbian province of Kosovo epitomised this: "You should stay here for the sake of your ancestors and descendants", he advised those Serbs, many of whom felt besieged by Albanians in the province. „Would you shame your ancestors and disappoint your children? But I don't suggest that you stay, endure and tolerate a situation you are not satisfied with. We will win this battle! Serbia does not exist without Kosovo" (S. Milosevic in Scharf and Schabas 2002,10). This sort of statement invoked a common relationship to an ,eponymous ancestor" (Verdery 1996, 73), and at the same time, „referred to the timelessness of Serbian national identity, fusing past, present, and future", while praising the Serbian character and claiming that they had an ancestral duty to fight for what was theirs (Morus 2007, 9).

And in 2015, over a quarter of a century later, President Aleksandar Vučić told Serbs living in Kosovo that „Kosovo is a cradle of Serbia. We will never forget Kosovo. We as Government of Serbia will continually engage to create as much as possible working places here and a better welfare for Serbs". ${ }^{3}$ The similar reference to an almost primordial shared history as the basis for contemporary

${ }^{3}$ A. Vučić, in Gazeta Express, 14 January 2015. 
Serbian national identity was overtly expressed, and through this connection, an ancestral obligation to assert this identity - even in the face of opposition - was thus galvanised.

Yet, despite references to historical ties and the sense of continuity with the past that such statements imply, the emergence of new forms of cultural expression and cultural identity effectively become more ,hybrid forms of life and art that do not have a prior existence within the discrete world of any single culture or language" (Bhabha 1994, xiii), and that potentially displace some of the strands of identity that preceded them.

The theme of an independent people who resist outside aggression has been a salient one in the reconstructed Serbian national identity since the 1990s. History is frequently appropriated to validate this trait, with examples of Serbian defiance of the Ottoman Turks, and in the twentieth century, the Germans, used to demonstrate the paternity of this motif.

Reference to the Battle of Kosovo (1389) is the strongest of these resistance narratives. It combines a religious dimension (the Serbian Orthodox Christian Tsar Lazar being defeated by the Turkish Muslim Sultan Murad), a territorial dimension (in terms of the territory of Kosovo, which is imbued with notions of sacrifice and a quest for return), and an identity dimension (in which contemporary Serbs are in one sense an incarnation of those from the medieval period) (Bieber 2002, 95-96). History loses some of its temporal dimension when appropriated for the purposes of national identity, and becomes part of an eternal presence, or even a form of Nietzschean ,eternal recurrence” (Kain 2007, 53). In the 1990s, the Serbian academic Ivan Colović went as far as to argue that the wars that the Serbs were then embroiled in were „merely the continuation of their previous history or, to be more precise, [their]...mere repetition" (Čolović 1994, 91). The historian Radovan Samardžić has made this link with identity explicit, noting that ,[t] he Kosovo orientation is not [only] a national idea, but also a trait of character which makes a Serb a Serb" (Samardžić 1991, 14). And more recently, the theme of Serbian resistance to the German occupation in the Second World War (Jansen 2000, 412, 406, 49, 412) has fortified these themes of victimhood, persecution by external aggressors, and resilience, which form a triumvirate of traits that are representative of the current Serbian national identity.

Of course, the Ottoman Turks occupied Serbia, as did the Germans in the Second World War, but the spirit of defiance takes on a historic significance in the reconstruction of Serbian national identity that outweighs the fact of the ultimate failure of that resistance to prevent foreign occupation. This apparent dilemma is resolved by introducing a subsidiary theme: the eventual triumph over these occupiers. The Ottoman Turks eventually were pushed out of Serbia, as were the Germans. And so too will the current occupiers of Kosovo, according to this logic. It is a form of war of attrition that Serbs are prepared 
to fight for generations if necessary, and is embodied in the phrase „Kosovo is Serbia” („Kosovo je Srbija”) ${ }^{4}$ which transcends the temporal progression of history and supplants it with an aspiration of territorial and cultural resolution to be achieved because of the rectitude of reunification, rather than as a result of anything more practicable.

However, while many Serbs might hold such perspectives, and regard them to be true historically, and true for themselves individually as well as nationally, there is a paradox that is central to this outlook: the current belief that by not accepting Western demands for Serbia to recognise its province of Kosovo as an independent Albanian state, Serbia is challenging Western hegemony in the way it challenged Turkish and German hegemony in previous centuries. What is missing from such a populist national narrative, though, is the fact that Serbia is part of a hegemonic world system of mutually dependent parts, and that periodic shows of anti-systemic activity can give an illusion of defiance, but actually (because of their inevitable failure) serve to demonstrate the strength of that hegemonic system and the impotence of states that try to defy it (Wallerstein 1990, 288-289). So while the theme of Serbian resistance to greater powers extending to the notion of ,inat": ,an irrational defiance against all odds" (Ejdus 2012, 230; Jovanović 2008) - has become a pronounced aspect of the reconstituted Serbian national identity since the 1990s, it conversely creates a new subservient space for Serbia in the same hegemonic system it resists (Bhabha 1994, 169). However, it is the act of resistance, rather than its effectiveness, that is the predominate consideration in this aspect of the reconstructed Serbian national identity, and although it has historical precedent, its re-emergence in the post-Yugoslavia era is more a mechanism of coping with temporary challenges as opposed to being the continuation of a trait that existed previously (and that lay dormant for most of the period of Yugoslavia's existence).

Yet, at the same time that the contemporary Serbian national identity orients itself against the power and incursions of bodies such as the European Union, there is also an orientation towards the culture and values of Western Europe. This can be seen, for example, in the comparatively rapid shifts in attitudes towards homosexuality in Serbia. In 1994, Serbia decriminalised homosexual sex, and after years of threats of violence and actual violence if such a concession was made (Mikuš 2011). The first relatively trouble-free gay pride parade took place in Belgrade in 2015; 5 two later, Serbia's first openly gay Prime Minister, Ana Brnabić, was appointed; and in September 2017, Brnabić became the first Serbian Prime Minister to take part in the Belgrade Pride Parade.

4 T. Spaić, „Kosovski Zavet”, Blic (22 February 2008).

5 Belgrade Pride, „USPEH: Beograd Prajd 2014 - „Nova Strana Istorije!” (1 October 2014). 
There are several points of significance about these developments, and how they intersect with the ongoing processes of reconstructing Serbian national identity. The first one is that most of the transitions relating to Serbia's attitudes to homosexuality at a state level have occurred partly as a result of pressure applied by the European Union, for which legislation granting equal rights to the gay community is one of the prerequisites for European Union membership (Kahlina 2015, 1-3). Complying with demands from other states undermines the element of defiance of external intervention that is supposed to be a defining trait of Serbian national identity, and is particularly paradoxical given that Serbia's decriminalisation of homosexuality, in 1994, took place against a backdrop of popular opposition to homosexuality in Serbian society.

The second significant point in relation to the advance of gay rights in Serbia is that it exposes a divide between young and old, and urban and rural on this issue (Bilić and Stubbs 2015; Volčić 2005). Such divides are not unique to Serbia, and regionally are closely mirrored in Croatia (Glaurdić and Vuković 2016, 813-814). However, the fact of these divides reveals that there is not a single, unified Serbian stance on gay rights. This is to be expected in any pluralistic society, but its relevance in the context of this review is that it highlights how rapidly the national traits of Serbs are evolving and are in a perpetual state of flux (as opposed to Kapferer's argument view that nationalist constructions of identity tend to be conceptually static) (Kapferer 2011, viii).

Another important aspect of the advance of gay rights in Serbia since the breakup of Yugoslavia has been the implicitly diminished influence it reveals the Serbian Orthodox Church exercising. The Church has been a staunch critic of gay rights in the country, but what makes this relationship so consequential is that the Church has been widely regarded as an essential and even indispensable component of Serbian national identity (Iveković 2002; Vukomanović 2008). It is at this juncture that some of the complexities of the markers of Serbian national identity become apparent. While the Church is firmly opposed to the state's position on gay rights, at the same time, the Church has benefitted materially, and in its growth in social and political status and influence in post-Yugoslavia Serbia (Vukomanović 2008; Vukomanović 2014).

Reconciling these apparent contradictions can be difficult, but the fact that they exist could, in themselves, be markers of some facets of modern Serbian national identity, and in particular, the extent of pluralism it encompasses. A strain of ambivalence remains nonetheless, and can be explained by Jacques Lacan's conception of mimicry, in which national communities acquire, or appear to acquire, the values of outside groups as a form of camouflage: „It is not a question of harmonizing with the background, but against a mottled background, of becoming mottled" (Lacan 1978, 99). 
Another aspect of hybridity in the context of a reconstructed Serbian national identity is the role of race. At times of national crisis, including the disintegration of Yugoslavia and the ensuing wars, and the NATO aggression in 1999 followed by anti-Serb pogroms in the country's southern province of Kosovo, the issue of race has surfaced as part of political rhetoric, which to a degree acts as a mirror, reflecting popular national beliefs about the role of race as a trope in Serbian national identity, and in particular, reinforcing a tacit beliefs in ethnic exclusivity and even superiority. It is seldom expressed this crudely, but there are numerous references over the past three decades to the "Serbian people", in a way that in practice makes ,people” almost interchangeable with „race” (Oberschall 2000, 997; Ratcliffe 2004, 28; Appleby and Scott 2012, 14; Pešić 2007, 3-5; for an outside perspective on the Serb 'race', see Trbovich 2007, 215).

Robert Young has addressed this feature of political, cultural, and social discourse, noting that there is no biological or other objectively evidential basis for the claims of a discrete race anywhere, and that the world exists in a state of „raceless chaos” (Young 1995, 25). Racial or ethnic hybridity is the norm almost everywhere in the world, and certainly in Europe, where millennia of the movement of peoples undermine any claims to racial distinctiveness, let alone purity (Acheraïou 2011; Gilroy 2000, 37, 41). Much of the rhetoric of „the Serbian people" in the past three decades has blurred the lines between notions of racial purity and those of cultural purity, thus fusing together genetic issues with social constructs. Even if overt claims of racial separateness are seldom heard (especially as the reconstruction of Serbian national identity orients itself closer to Western European values regarding ethnicity), this does not mean that beliefs about the Serbian ,race" and its position in the region have been expunged from the popular imagination.

\section{Homogeneity in Contemporary Serbian Identity}

Various aspects of the theme of homogeneity in the reconstruction of Serbian national identity have been alluded to in the preceding section. What is examined here are those forces, institutions, and beliefs that contribute to this homogeneity, and that endeavour to sustain it through rapidly-changing internal and external environments.

The basis of a homogeneous Serbian national identity is a contingent formulation that arises and is maintained ,from contested social fields of difference and sameness" (Postero 2013, 108; Friedlander 1975), and requires both discursive and symbolic forms of cultural reconstruction (Harris 1995). This homogeneity relies both on defining and differentiating from the Other (Brubaker 1995; Eriksen 2002, 39, 159-160), but more importantly, on a construction of a 
specifically Serbian cultural, linguistic and social eco-system (Gadgil and Guha 1995, 3). This is an archetype which does not exist, but the traces of which are identified in small, isolated, usually aging rural-based communities which are largely subsistence-based, and which have shrinking populations (Buell 2003, 184). This idealised model of „true" Serbian national identity is beset by contradictions: it represents a fraction of the Serbian population as a whole, and is declining in numbers precisely because it does not so much reflect an ideal that people lean towards as one that they look back on. It is thus nostalgic rather than utopian, and draws its strength as an ideal principally from the presumption that it represents a „purer” image of Serbian culture and society. This imagined purity, in turn, stems from the belief that such rural communities supposedly depict a microcosm of Serbian culture and society at a time when it was less influenced by external factors. These types of idealisations are as much a generalised response to the threat that globalisation presents to cultural and social homogeneity as they are a homage to a particular way of living that is now no longer a part of everyday life for the vast majority of Serbs (Volčić and Erjavec 2009; Ramet 1996; Simić 1973).

Self-identification as a Serb is a central criteria in the reconstructed Serbian national identity, particularly as such overt identifications were far more problematic in Yugoslavia during the Tito era (Hodson, Sekulić and Massey 1994, 1534-1558; Gagnon 1994, 143). There is a spectrum of self-identification, ranging from nominating an identity in a survey or census, through to exhibiting (and possibly performing) traits that are perceived as enhancing idealised notions of the identity in question (Weaver 2001). Of course, this is an issue of identity at an individual level, which, as Social Identity Theorists point out, also needs to find a form of expression as part of a group identity (Brown 2000, 747; Oakes and Turner 1980, 295-302). The homogeneous nature of Serbian national identity, in its recently-constructed form, comprises of a number of markers, including being connected by a common religion, geography, tradition, ethnicity, and history. Integration into this model, and compliance with its markers, is a prerequisite to be regarded as an ,authentic" member of the group (Durham and Godfrey 1993). An additional aspect of membership of a national group is that self-identification with the group is confirmed by others who claim the same identity. The shared sense of identity can be enhanced further by shared claims of association with social or cultural institutions that are unique to the group especially of those institutions have a strong historical presence and pre-date the current iteration of the state (Griffin-Pierce 1997, 1-10; Weaver 2001, 245). In the case of Serbian identity, membership of the Serbian Orthodox Church is one of the key markers of this reconstructed identity, although in complex and sometimes contradictory ways. 
The autocephalous Serbian Orthodox Church emerged around the tenth century (Vlasto 1970, 208), making it the oldest Serbian institution that has been in continual existence since its inception. Much of Serbian history has been intimately tied up with the Church (Iveković 2002; Kitromilides 1989; Vukomanović 2008; Leustean 2008), although during communist-era Yugoslavia, the state actively discriminated against it and suppressed its influence. The collapse of communism, followed by the collapse of Yugoslavia, reinvigorated the Serbian Orthodoxy, establishing it again as playing a role at the forefront of reconstructed Serbian national identity.

However, its role is an intricate and nuanced one for several. Firstly, while the Church is ostensibly Serbian, it has formal, and increasingly intimate relations with the Russian Orthodox Church (Evans 2002, 39-41; The Russian Orthodox Church, Department for External Church Relations 2014; Savich 2017). This pan-national element is not merely religious, though. It also reflects Orthodoxy more generally positioning itself geopolitically as a counter to its perception of the Western world as being excessively liberal and secular (Demacopoulos and Papanikolaou 2013). Affiliation with the Church as part of the reconstructed Serbian national identity (and the rise of Serbian „desecularization" from the early 1990s) (Blagojevic 2008, 37-49) also means an implicit orientation towards Russian Orthodoxy, which in addition to being theologically identical for all intents and purposes is also perceived as having a shared Slavic heritage (Danilevskii 2013), and facing similar types of social and moral pressures from the West (Selbach 2002).

The Serbian Orthodox Church's relationship with the Serbian state is often ambiguous, and adds another nuance to its role in national identity. Although the Serbian Constitution specifies the separation of church and state, emphasising that the country ,is a secular state [....] Churches and religious communities shall be separated from the state", and that ,[n]o religion may be established as state or mandatory religion", ${ }^{6}$ in practice, there are de facto connections that blur the boundaries between the two. As Dr Rada Drezgić has argued, Serbia has experienced a form of religious nationalism since 2000, in which ,religion and religious institutions to enter all the pores of social life". As she describes the relationship, ,the political elites used religion to legitimise their claim to power, while religious communities used nationalism for their own rehabilitation and reaffirmation. Thus, the national(ist) programme as their common project has connected the high ranks of the Church with the centres of political power" (Drezgić 2010, 956, 957, 961). However, this intersection between Church and

6 The Constitution of the Republic of Serbia, adopted by the National Assembly of the Republic of Serbia at a special session on 30 September 2006, and endorsed by referendum on 28 and 29 October 2006, art. 11. 
government serves to strengthen both institutions, and in the context of a reconstructed Serbian national identity, positions the Serbian Orthodox Church as the single largest and most influential extra-governmental institution in the country - a position the Church has not enjoyed since before the Second World War. However, as Dubravka Stojanović has observed, historically, ,government, civil society and society at large, existed almost independently from one another. Civil society institutions failed to propel the slow and almost undifferentiated society, and they were never strong enough to curtail the state and seriously direct it towards more complete forms of democracy", and this disjunctive element of Serbian society "grew more complex in the twentieth century" (Stojanović 2017, 27-8,33) resulting in a factionalism among the institutions of the state and society, which are reflected in the ambiguous role of the church (when depicted as a de facto part of the state).

The fact that there is a religious dimension to this aspect of contemporary Serbian identity (even if the adherence is nominal or cultural rather that devoutly religious in basis) imbues that identity with a sanctity that could not readily be obtained elsewhere, and provides rituals of adherence that merge religious practice with national identity, while also serving as a counterbalance to the state-sponsored post-war Yugoslav atheism (Roter 1989, 2). With the resurgence of the Serbian Orthodox Church since the 1990s, the atheism of the Yugoslav state can implicitly be linked in the popular imagination with a time when the Serbian national identity was considerably weaker or even suppressed.

Hobsbawm suggested that ,[n]ations without a past are a contradiction in terms" (Hobsbawm and Kertzer 1992, 3), and it is this link to the past that the Church offers that makes its contribution to Serbian identity unique. Not only has it been present during most of the history of the country, but its iconography often recalls that history visually, while its liturgy is conducted in Old Slavonic, which resonates with and accentuates the antiquity of the institution (Borowik 2006, 267-278).

\section{Conclusion: A settled identity?}

Perhaps the most salient feature of this process of Serbian identity-reconstruction is the fact that it remains unsettled. Two of the reasons for this are both externally-sourced: the East-West polarity that continues to shape Serbian foreign policy and cultural orientation, and the subversive role of globalisation on a distinct Serbian identity.

The East-West polarity has historical roots (including the Orthodox faith shared with other Eastern European countries, and a similarly shared Slavic origin), and more contemporary causes - particularly the mutual polarity Serbia 
experience with Croatia, which is Catholic rather than Orthodox, and politically leans more to the West than the East. From a Hobsbawmian perspective, both Serbia and Croatia are „new” states, and therefore are forced to compensate for this fact by drawing on histories that make each of them seem as though they have an unbroken paternity with past states and events, and one which separates them from their neighbours. When considered through the lens of Social Identity Theory, the traces of xenophobia sometimes evident in Serbian-Croatian relations (and which are often justified among both groups by evocations of history) is part of the stereotyping of each group by the other, with the aim to consolidate the strength of identity within each group (Brown 2000, 748; Brown, Vivian, and Hewstone 1999, 741-746).

One of the other principle reasons for the fact that Serbia's national identity is less certain than adherents may think is the impact of globalisation on the country and its people. As the case of gay rights in Serbia illustrates, the traditional authority of the Church as moral arbiter for the country has been partially undermined by the influence brought to bear on Serbia from more liberal, secular Western nations (Jovanović 2013, 79-95; Ristić 2007, 185-195). This creates a tension as to what the centre of influence for some aspects of contemporary Serbian national identity is. The tension is maintained because there are two main centres: one external and seemingly subversive, the other internal, and either reactionary or focussed on notions of re-traditionalization. The friction or tensions produced when these two come into contact prevents Serbian identity remaining comparatively static, in the ways that identities are more inclined to do in some Western European countries, and thus function as active components in the redefinition of the Serbian identity. It would be mistaken, though, to view such tensions and cross-currents of contemporary Serbian national identity as a form of deficit in national character. Rather, what is evident from this survey is that the reconstruction of that identity is a work-in-progress, and that while some elements of what it means to be Serbian may remain relatively constant, in other areas, redefinition will continue to be the norm as the internal and external (among other) dynamics continue to work themselves through Serbian culture and society.

\section{Bibliography and Sources}

Acheraïou, A. 2011. Questioning Hybridity, Postcolonialism and Globalization. London: Palgrave.

Appleby R. S. and Scott, R. 2012. Religious Violence: The Strong, The Weak, and The Pathological. Practical Matters 5: 1-25.

Banac, I. 1990. Political Change and National Diversity. Daedalus 119 (1): 141-159. Barth, F. 1998. Ethnic Groups and Boundaries: The Social Organisation of Culture

Difference. Illinois: Waveland Press. 
Belgrade Pride. 2014. „USPEH: Beograd Prajd 2014 - „Nova Strana Istorije!” 1 October 2014.

Bhabha, H. K. 1994. The Location of Culture. Oxford: Oxford University Press.

Bieber, F. 2002. Nationalist Mobilization and Stories of Serb Suffering: The Kosovo Myth from 600th Anniversary to the Present. Rethinking History 6 (1): 95-110.

Bilić, B. and Stubbs, P. 2015. „Unsettling ‘The Urban' in Post-Yugoslav Activisms: 'Right to the City' and Pride Parades in Serbia and Croatia". In Urban Grassroots Movements in Central and Eastern Europe ed. Jacobson K., 119-138. London: Routledge.

Blagojević, M. 2008. Desecularization of Contemporary Serbian Society. Occasional Papers on Religion in Eastern Europe 28 (1): 37-49.

Borowik, I. 2006. Orthodoxy Confronting the Collapse of Communism in Post-Soviet Countries. Social Compass 53 (2): 267-278.

Brown, R. J., Vivian, J., and Hewstone, M. 1999. Changing Attitudes through Intergroup Contract: The Effects of Membership Salience. European Journal of Social Psychology 29: 741-764.

Brown, R. 2000. Social Identity Theory: Past Achievements, Current Problems and Future Challenges. European Journal of Social Psychology 30 (6): 745-778.

Brubaker, R. 1995. National Minorities, Nationalizing States, and External National Homelands in the New Europe. Daedalus 124 (2): 107-132.

Brubaker, R. and Cooper, F. 2000. Beyond „Identity”. Theory and Society 29 (1): 1-47.

Buell, L. 2003. „Theorising the National in a Spirit of Due Reluctance”. In Theories of American Culture, Theories of American Studies, eds. Fluck, W. and Claviez, T., 177-200. Tübingen: Narr Verlag.

Burg, S. L. and Berbaum, M. L. 1989. Community, Integration, and Stability in Multinational Yugoslavia. American Political Science Review 83 (2): 535-554.

Caspersen, N. 2008. Between Puppets and Independent Actors: Kin-state Involvement in the Conflicts in Bosnia, Croatia and Nagorno Karabakh. Ethnopolitics 7 (4): 357-372.

Cirković, S. 1994. Historiography in Isolation-Serbian Historiography Today. Helsinki Monitor 5: 35-40.

Čolović, I. 1994. „Die Erneuerung des Vergangenen”. In Bosnien und Europa. Die Ethnisierung der Gesellschaft, eds. Stefanov, N. and Werz, M., 90-104. Frankfurt: Fischer.

Congressional Quarterly. 2013. The Powers of the President, 4th edn Thousand Oaks: Sage Publications.

Ćosić, D. 1989. „Ima li smisla pristajanje na svaku Jugoslaviju?” In Borba, Belgrade, 13 June 1989.

Danilevskii, N. 2013. Russia and Europe: The Slavic World's Political and Cultural Relations with the Germanic-Roman West (Woodburn, S., trans.). Indianna: Slavica Publishers.

Demacopoulos, G. E. and Papanikolaou, A. eds. 2013. Orthodox Constructions of the West. New York: Fordham University Press.

Demacopoulos, G. E. and Papanikolaou, A. 2013. „Orthodox Naming of the Other: A Postcolonial Approach". In Orthodox Constructions of the West, eds. Demacopoulos, G. E. and Papanikolaou, A., 1-22. New York: Fordham University Press.

Dimou, A. ed. 2009. "Transition” and the Politics of History Education in Southeast Europe. Göttingen: V\&R Unipress. 
Djuretić, V. ed. 1991. Kosovska bitka i posledice. Belgrade: SANU.

Drezgić, R. 2010. Religion, Politics and Gender in the Context of Nation-State Formation: The Case of Serbia. Third World Quarterly 31 (6): 995-970.

Durham, J. and Godfrey, T. 1993. A Certain Lack of Coherence: Writings on Art and Cultural Politics. London: Kala Press.

Economides, S. and Ker-Lindsay, J. 2015. 'Pre-Accession Europeanization': The Case of Serbia and Kosovo. JCMS: Journal of Common Market Studies 53 (5): 1027-1044.

Ejdus, F. 2012. „State Building and Images of the Democratic Soldier in Serbia”. In Democratic Civil-military Relations: Soldiering in 21st-century Europe, ed. Mannitz, S., 226-248. London: Routledge.

Eriksen, T. H. 2002. Ethnicity and Nationalism: Anthropological Perspectives. London: Pluto Press.

Erikson, E. H. 1980. Identity and the Life Cycle. New York: W. W. Norton \& Co.

Evans, A. 2002. Forced Miracles: the Russian Orthodox Church and Postsoviet International Relations Religion. State \& Society 30 (1): 33-43.

Fluck, W. and Claviez, T., eds. 2003. Theories of American Culture, Theories of American Studies. Tübingen: Narr Verlag.

Friedlander, J. 1975. Being Indian in Hueyapan, A Study of Forced Identity in Contemporary Mexico. New York: St Martin's Press.

Friedman, T. L. 1993. „Conflict in the Balkans: Clinton says He's ready to Hit Serbs Attacking U.N. in Bosnia”, New York Times, 29 July 1993.

Gadgil, M. and Guha, R. 1995. Ecology and Equity: The Use and Abuse of Nature in Contemporary India. London: Routledge.

Gagnon, V. P. 1994. Ethnic Nationalism and International Conflict: The Case of Serbia. International Security 19 (3): 130-166.

Gazeta Express, 14 January 2015.

Gellner, E. 2008. Nations and Nationalism. New York: Cornell University Press.

Gilroy, P. 2000. Against Race: Imagining Political Culture Beyond the Color Line. Cambridge MA: Harvard University Press.

Glaurdić, J. and Vuković, V. 2016. Proxy Politics, Economic Protest, or Traditionalist Backlash: Croatia's Referendum on the Constitutional Definition of Marriage. Europe-Asia Studies 68 (5): 803-825.

Gonzalez, R. and Brown, R. 1999. „,The Role of Categorization, Group Status and Group Size in Mediating Inter-nation Attitudes in the European Union". Paper presented to the BPS Social Psychology Section Conference, Lancaster, September 1999.

Goulding, C. and Domic, D. 2009. Heritage, Identity and Ideological Manipulation: The Case of Croatia. Annals of Tourism Research 36 (1): 85-102.

Greenberg, R. D. 1996. The Politics of Dialects among Serbs, Croats, and Muslims in the Former Yugoslavia. East European Politics and Societies 10 (3): 393-415.

Greenberg, R. D. 2004. Language and Identity in the Balkans: Serbo-Croatian and its Disintegration. Oxford: Oxford University Press.

Griffin-Pierce, T. 1997. When I Am Lonely the Mountains Call Me: The Impact of Sacred Geography on Navajo Psychological Well-Being. American Indian and Alaska Native Mental Health Research Journal 7 (3): 1-10. 
Guzina, D. 2003. Socialist Serbia's Narratives: From Yugoslavia to a Greater Serbia. International Journal of Politics, Culture, and Society 17 (1): 91-111.

Harris, O. 1995. „Ethnic Identity and Market Relations: Indians and Mestizos in the Andes." In Ethnicity, Markets, and Migration in the Andes: at the Crossroads of History and Anthropology. eds. Larson, B. and Harris, O., 351-390. Durham: Duke University Press.

Hislope, R. 1996. Intra-ethnic conflict in Croatia and Serbia: Flanking and the consequences for democracy. East European Quarterly 30 (4): 471-494.

Hobsbawm, E. J., and Kertzer, D. J. 1992. Ethnicity and Nationalism in Europe Today. Anthropology Today 8 (1): 3-8.

Hobsbawm, E. 2012. Nations and Nationalism since 1780: Programme, Myth, Reality. Cambridge: Cambridge University Press.

Hobsbawn, E. 1972. „Some Reflections on Nationalism”. In Imagination and Precision in the Social Sciences. ed. Nossiter, T. J., Rokkan, S, and Hanson A. H., 385-406. London: Faber.

Hodson, R., Sekulić, D. and Massey, G. 1994. National Tolerance in the Former Yugoslavia. American Journal of Sociology 99 (6): 1534-1558.

Iveković, I. 2002. Nationalism and the Political Use and Abuse of Religion: The Politicization of Orthodoxy, Catholicism and Islam in Yugoslav Successor States. Social Compass 49 (4): 523-536.

Jacobson K. ed. 2015. Urban Grassroots Movements in Central and Eastern Europe. London: Routledge.

Jansen, S. 2000. Victims, Underdogs and Rebels: Discursive Practices of Resistance in Serbian Protest. Critique of Anthropology 20 (4): 393-419.

Jost J. T. and Sidanius J. eds. 2004. Political Psychology: Key Readings. New York: Psychology Press.

Jovanović, B. 2008. Prkos i inat: Etnopsihološke studije. Belgrade: Zavod za udžbenike, Jovanović, M. 2013. Silence or Condemnation: The Orthodox Church on Homosexuality in Serbia. Družbosand Cultural Relations with the Germanic-Roman Westlovne Razprave 29 (73): 79-95.

Kahlina, K. 2015. Local Histories, European LGBT Designs: Sexual Citizenship, Nationalism, and „Europeanisation” in post-Yugoslav Croatia and Serbia. Women's Studies International Forum 49: 73-83.

Kain, P. J. 2007. Nietzsche, Eternal Recurrence, and the Horror of Existence. The Journal of Nietzsche Studies 33 (1): 49-63.

Kapferer, B. 2011. Legends of People, Myths of State: Violence, Intolerance, and Political Culture in Sri Lanka and Australia. New York: Berghahn Books.

Kitromilides, P. M. 1989 „Imagined Communities” and the Origins of the National Question in the Balkans. European History Quarterly 19 (2): 149-192.

Lacan, J. 1978. The Four Fundamental Concepts of Psycho-Analysis. (A. Sheridan, trans.). New York: Norton.

Larson, B. and Harris, O. eds. 1995. Ethnicity, Markets, and Migration in the Andes: at the Crossroads of History and Anthropology. Durham: Duke University Press.

Lemyre, L. and Smith, P. M. 1985. Intergroup Discrimination and Self-esteem in the Minimal Group Paradigm. Journal of Personality and Social Psychology 49: 660-670. 
Lendvai, P. 1991. Yugoslavia without Yugoslavs: The Roots of the Crisis. International Affairs 67 (2): 251-261.

Leustean, L. N. 2008. Orthodoxy and Political Myths in Balkan National Identities. National Identities 10 (4): 421-432.

Ljubesic, N., Mikelic, N. and D. Boras, 2007. „Language Identification: How to Distinguish Similar Languages?" Information Technology Interfaces, 2007. ITI 2007. 29th International Conference, Cavtet: IEEE.

Mannitz, S. ed. 2012. Democratic Civil-military Relations: Soldiering in 21st-century Europe. London: Routledge.

Mikuš, M. 2011. „State Pride” Politics of LGBT Rights and Democratisation in „European Serbia". East European Politics and Societies 25 (4): 834-851.

Miličević, M. 2017. Creation and Some Ideas for Classroom Use of an Electronic Corpus of the Dialect of Bunjevci. Едищија ФИЛОЛОШКА ИСТРАЖИВАҢА ДАНАС TOM VII. Belgrade: University of Belgrade,

Milosević, S. 1989. Godine raspleta. Belgrade: BIGZ.

Morus, C. 2007. Slobo the Redeemer: the Rhetoric of Slobodan Milosevic and the Construction of the Serbian „People”. Southern Communication Journal 72 (1): 1-19.

Nossiter, T. J., Rokkan, S, and Hanson A. H. eds. 1972. Imagination and Precision in the Social Sciences. London: Faber.

Oakes, P. J. and Turner, J. C. 1980. Social Categorization and Intergroup Behaviour: Does Minimal Intergroup Discrimination Make Social Identity More Positive. European Journal of Social Psychology 10: 295-301.

Oberschall, A. 2000. The Manipulation of Ethnicity: From Ethnic Cooperation to Violence and War in Yugoslavia. Ethnic and Racial Studies 23 (6): 982-1001.

Ognjenović, G. and Jozelić, J. eds. 2014. Politicization of Religion, the Power of State, Nation, and Faith. New York: Palgrave Macmillan.

Pavković, A. 1998. From Yugoslavism to Serbism: The Serb National Idea 1986-1996. Nations and Nationalism 4 (4): 511-528.

Pešić, V., Ethnic Mobilization in Serbia: Report for MIRICO: Human and Minority Rights in the Life Cycle of Ethnic Conflicts. Bolzano, March, 2007.

Pesić, V. 1996. Serbian Nationalism and the Origins of the Yugoslav Crisis. Washington, DC: United States Institute of Peace.

Postero, N. 2013. Introduction: Negotiating Indigeneity. Latin American and Caribbean Ethnic Studies 8 (2): 107-121.

Ramet, S. P. 1996. Nationalism and the 'Idiocy' of the Countryside: The Case of Serbia. Ethnic and Racial Studies 19 (1): 70-87.

Ratcliffe, P. 2004. Race Ethnicity and Difference: Imagining The Inclusive Society: Imagining the Inclusive Society. London: McGraw-Hill Education UK.

Ristić, I. 2007. Serbian Identity and the Concept of Europeanness. Panoeconomicus 54 (2): 185-195.

Roter, Z. 1989. The Position of Believers as Second-Class Citizens in Socialist Countries: The Case of Yugoslavia. Occasional Papers on Religion in Eastern Europe 9 (3): 1-18. Samardžić, R. 1991. „Für das Himmlische Reich”. In Kosovska bitka i posledice. ed Djuretić, V., 9-14. Belgrade: SANU. 
Savich, C. 2017. „Russian Succor for the Serbian Orthodox Church”, Serbianna, 10 November 2017.

Scharf, M. P. and Schabas, W. A. 2002. Slobodan Milosevic on Trial: A Companion. New York: Continuum International Publishing Group, Inc.

Sciolino, E. 1994. „Clinton Supports Wider Air Strikes Against the Serbs”, New York Times, 20 April 1994.

Sekulić, D., Massey, G. and Hodson, R. 1994. Who were the Yugoslavs? Failed Sources of a Common Identity in the Former Yugoslavia. American Sociological Review 59 (1): 83-97.

Selbach, C. 2002. The Orthodox Church in Post-Communist Russia and her Perception of the West: A Search for a Self in the Face of an Other. Zeitschrift für Religionswissenschaft 10 (2): 131-174.

Simić, A. 1973. Kinship Reciprocity and Rural-Urban Integration in Serbia. Urban Anthropology 2 (2): 205-213.

Sobel, R. 1998. Trends: United States Intervention in Bosnia. The Public Opinion Quarterly 62 (2): 250-278.

Spaić, T. 2008. „Kosovski Zavet”, Blic, 22 February 2008.

Stamatović, M. and Zakić, N. 2010. Effects of the Global Economic Crisis on Small and Medium Enterprises in Serbia. Serbian Journal of Management 5 (1): 151-162.

Stedman, S. J. 1992. The New Interventionists. Foreign Affairs 72 (1): 1-16.

Stefanov, N. and Werz, M. eds. 1994. Bosnien und Europa. Die Ethnisierung der Gesellschaft. Frankfurt: Fischer.

Stojanović, D. 2009. „Slow Burning: History Textbooks in Serbia, 1993-2008”. In "Transition” and the Politics of History Education in Southeast Europe, ed. Dimou, A., 141-158. Gőttingen: V\&R Unipress.

Stojanović, D. 2017. „Oil on Water”. In Populism the Serbian Way. Belgrade: Peščanik. Tajfel, H. and Turner, J. C. 2004. „The Social Identity Theory of Intergroup Behavior”. In Political Psychology: Key Readings. eds. Jost J. T. \& Sidanius J., 276-293. New York: Psychology Press.

Tajfel, H. 1981. „Social stereotypes and social groups”. In Intergroup Behaviour, ed. Turner J. and Giles H., 144-167. Oxford: Oxford University Press.

The Constitution of the Republic of Serbia, adopted by the National Assembly of the Republic of Serbia, 30 September 2006.

The Russian Orthodox Church, Department for External Church Relations, „Primates of the Russian and Serbian Orthodox Churches Celebrate at the Cathedral of St. Sava of Serbia", 16 November 2014.

Trbovich, A. S. 2007. Nation-building Under the Austro-Hungarian Sceptre: Croato-Serb Antagonism and Cooperation. Balcanica XXXVII: 195-220.

Turner J. and Giles H., eds. 1981. Intergroup Behaviour. Oxford: Oxford University Press.

Verdery, K. 1996. What was Socialism, and What Comes Next? Princeton: Princeton University Press.

Vlasto, A. P. 1970. The Entry of the Slavs into Christendom. Cambridge: Cambridge University Press.

Volčić, Z. 2005. Belgrade vs. Serbia: Spatial Re-configurations of Belonging. Journal of Ethnic and Migration Studies 31 (4): 639-658. 
Volčić, Z. and Erjavec, K. 2009. Nostalgia for Greater Serbia: Media Coverage of Radovan Karadžić's Arrest. Journal of Global Mass Communication 11 (1/2): 24-46.

Vukomanović, M. 2008. The Serbian Orthodox Church as a Political Actor in the Aftermath of October 5, 2000. Politics and Religion 1 (2): 237-269.

Vukomanović, M. 2014. „Ecclesiastical Involvement in Serbian Politics: Post-2000 Period". In Politicization of Religion, the Power of State, Nation, and Faith, eds. Ognjenović, G. and Jozelić, J., 115-149. New York: Palgrave Macmillan.

Wallerstein, I. 1990. World-Systems Analysis: The Second Phase. Review Fernand Braudel Center 13 (2): 287-293.

Weaver, H. N. 2001. Indigenous Identity. American Indian Quarterly 25 (2): 240-255.

Weinstein, H. M., Freedman, S. and Hughson, H. 2007. School Voices: Challenges Facing Education Systems After Identity-based Conflicts. Education, Citizenship and Social Justice 2 (1): 41-71.

Young, R. J. C. 1995. Colonial Desire: Hybridity in Theory, Culture, and Race. New York: Routledge.

Paul Moon

Tehnološki univerzitet u Oklandu, Novi Zeland

\section{Rekonstrukcija srpskog nacionalnog identiteta u post-jugoslovensko doba: tematsko ispitivanje}

Ovaj rad ispituje neke od izazova s kojima se suočava Srbija pri rekonstrukciji sopstvenih elemenata nacionalnog identiteta, posle raspada Jugoslavije tokom devedesetih godina prošlog veka. Za razliku od ostalih republika koje su činile federaciju, Srbija je nastojala da očuva tu federaciju do te mere da je bila najmanje nacionalistička od svih republika početkom devedesetih. Međutim, kako se Jugoslavija raspadala (dezintegrisala) tokom te decenije, Srbija je bila prisiljena da rekonstruiše svoj identitet na načine koji su odražavali okolnosti bez presedana s kojima se zemlja suočavala. Rad istražuje elemente neprekidnosti procesa rekonstrukcije identiteta Srbije još od devedesetih godina, usredsređujući se na odlike hibridizovanog nacionalnog identiteta, uticaj istorijskih tropâ, kao i na tenzije između kulturne homogenosti i subverzivnih efekata globalizacije na taj identitet. Iz ove studije proizlazi da je savremeni srpski nacionalni identitet postao dinamičan i razvojni konstrukt, koji neprekidno biva redefinisan kao odgovor na unutarnje tenzije i spoljne pritiske.

Ključne reči: Srbija, istorija, homogenost, hibridnost, identitet, kultura, pravoslavlje, religija, nacionalizam 
Reconstruction de l'identité nationale serbe à l'âge post-yougoslave: examen thématique

Cette étude examine certains des défis auxquels est confrontée la Serbie lors de la reconstruction de ses propres éléments d'identité nationale, après la désintégration de la Yougoslavie au cours des années quatre-vingt-dix du siècle passé. À la différence des autres républiques qui faisaient partie de la fédération, la Serbie s'efforçait de conserver cette fédération à tel point qu'elle était la moins nationaliste de toutes les républiques au début des années quatre-vingt-dix. Cependant, comme la Yougoslavie s'était désintégrée au cours de cette décennie, la Serbie était obligée de reconstruire son identité d'une manière qui ne faisait que refléter les circonstances sans précédent auxquelles le pays était confronté. Notre étude questionne les éléments de continuité du processus de reconstruction de l'identité de la Serbie depuis les années quatre-vingt-dix, en se concentrant sur les caractéristiques de l'identité nationale hybride, l'influence des tropes historiques, ainsi que sur les tensions entre l'homogénéité culturelle et les effets subversifs de la globalisation sur cette identité. De cette étude découle que l'identité nationale serbe contemporaine est devenue un construct dynamique et évolutif, sans cesse redéfini comme une réponse à des tensions intérieures et des pressions extérieures.

Mots clés: Serbie, histoire, homogénéité, hybridité, identité, culture, orthodoxie, religion, nationalisme

Primljeno / Received: 3.04.2018.

Prihvaćeno / Accepted: 6.06.2018. 